\title{
Final Reclamation Report: Basalt Waste Isolation Project Exploratory Shaft Site
}

C. A. Brandt

W. H. Rickard, Jr.

June 1990

Prepared for the U.S. Department of Energy under Contract DE-AC06-76RLO 1830

Pacific Northwest Laboratory

Operated for the U.S. Department of Energy

by Battelle Memorial Institute 


\title{
DISCLAIMER
}

This report was prepared as an account of work sponsored by an agency of the United States Government. Neither the United States Government nor any agency thereof, nor Battelle Memorial Institute, nor any of their employees, makes any warranty, expressed or implied, or assumes any legal Ilability or responsibility for the accuracy, completeness, or usefulness of any information, apparatus, product, or process disclosed, or represents that its use would not intringe privately owned rights. Reference herein to any specific commercial product, process, or service by trade name, trademark, manufacturer, or otherwise, does not necessarily constitute or imply its endorsement, recommendation, or favoring by the United States Government of any agency thereof, or Battelle Memorial Institute. The views and opinions of authors expressed herein do not necessarily state or reflect those of the United States Government or any agency thereof.

\author{
PACIFIC NORTHWEST LABORATORY \\ operated by \\ BATTELLE MEMORIAL INSTITUTE \\ for the \\ UNITED STATES DEPARTMENT OF ENERGY \\ under Contract DE-AC06-76RLO 1830
}

Printed in the United States of America

Available to DOE and DOE contractors from the

Office of Scientific and Technical Information, P.O. Box 62, Oak Ridge, TN 37831; prices available from (615) 576-8401. FTS 626-8401.

Available to the public from the National Technical Information Service, U.S. Department of Commerce, 5285 Port Royal Rd., Springfield, VA 22161.

NTIS Price Codes, Microfiche A01

Printed Copy

\begin{tabular}{cr}
\hline Prke Code & Page Range \\
\hline A02 & $1-10$ \\
A03 & $11-50$ \\
A04 & $51-75$ \\
A05 & $76-100$ \\
A06 & $101-125$ \\
A07 & $126-150$ \\
A06 & $151-175$ \\
A09 & $176-200$ \\
A10 & $201-225$ \\
A11 & $226-250$ \\
A12 & $251-275$ \\
A13 & $276-300$ \\
A14 & $301-325$
\end{tabular}

\begin{tabular}{cc}
\hline Price Code & Page Range \\
\hline A15 & $326-350$ \\
A16 & $351-375$ \\
A17 & $376-400$ \\
A18 & $401-425$ \\
A19 & $426-450$ \\
A20 & $451-475$ \\
A21 & $476-500$ \\
A22 & $501-525$ \\
A23 & $526-550$ \\
A24 & $551-575$ \\
A25 & $576-600$ \\
A99 & $601-U p$
\end{tabular}


PNL-7379

UC-801

FINAL RECLAMATION REPORT:

BASALT WASTE ISOLATION PROJECT

EXPLORATORY SHAFT SITE

C. A. Brandt

W. H. Rickard, Jr.

June 1990

Prepared for the U.S. Department of Energy under Contract DE-AC06-76RLO 1830

Pacific Northwest Laboratory Richland, Washington 99352 


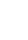




\section{SUMMARY}

An 11.4-ha facility was constructed on undisturbed big sagebrush-cheatgrass habitat in 1982 for the purposes of supporting drilling of a large-diameter exploratory shaft deep into the basalts underlying the Hanford Site. This work was terminated in December 1987, and reclamation efforts were begun. The goal of the reclamation program was to restore the site as nearly as practicable to its original condition using native plant species.

Demolition of the Exploratory Shaft Facility (ESF) began in 1988, and reseeding efforts were completed in November of that year. Revegetation consisted of broadcasting seeds of big sagebrush and grey and green rabbitbrush, followed by drillseeding the native grasses Sandberg bluegrass and bottlebrush squirreltail. Spiny hopsage tubeling plants were then set by hand in a triangular configuration at a density $30 \%$ greater than that in the surrounding habitat. The site was irrigated from March to June 1989 at a rate sufficient to make the cumulative precipitation on the site reach $2.5 \mathrm{~cm} / \mathrm{mo}$.

Two methods were used to estimate reclamation success: trend analysis and spatial analysis of plant counts or cover per unit area. These analytical methods were applied to revegetated sites and nearby control areas. Trend data were gathered over 2 years in control areas and over 1.5 years in revegetated areas. Examination of trends on the two types of areas allowed estimation of the eventual outcome of reclamation with regard to the average density of species planted or seeded on the site. Spatial analyses allowed comparison of the spatial variability in plant counts and cover. Successful reclamation sites should resemble the undisturbed habitat both in average density of revegetated plants as well as in their spatial distribution.

Plant cover on undisturbed plots was dominated by cheatgrass. Big sagebrush and grey rabbitbrush were the second and third most abundant species in terms of cover. The most common native grasses were Sandberg bluegrass, Indian ricegrass, and bottlebrush squirreltail. The most common shrub in terms of average density was grey rabbitbrush, followed by big sagebrush, green rabbitbrush, and spiny hopsage. Spatial variation accounted for $17.6 \%$ of the residual variance in percentage cover that was unexplained by species identity, and temporal variation accounted for $10.6 \%$. Spatial-temporal interaction accounted for only $1.4 \%$ of the residual variance. 
Sandberg bluegrass was the most common native species on the revegetated sites, although cheatgrass had the highest average cover. Both Sandberg bluegrass and bottlebrush squirreltail occurred in average densities higher than that in surrounding habitat; however, the average is misleading. Plants occurred at extremely high density in a few areas, and not at all in the majority of others. Cover by cheatgrass was highest on the ESF access road and least (absent) on the mound over the former drill rig pad. Russian thistle cover was highest on the pad and least on the mound. The only species present on the mound were Russian thistle and Sandberg bluegrass.

Shrub counts on the ESF were highest for grey rabbitbrush, followed by spiny hopsage. Approximately one third fewer spiny hopsage were alive in April 1990 than had been found alive in July 1989 . Big sagebrush did poorly and had an extremely patchy occurrence. Green rabbitbrush was not observed. No shrubs occurred on the mound area. Shrub numbers and percentage cover were both significantly lower on the ESF than in the surrounding habitat for all species except spiny hopsage.

Plant numbers of both seeded grasses declined markedly during the first year after seeding. Sandberg bluegrass numbers dropped by an order of magnitude on the revegetated area, but showed no significant change during the same period on undisturbed areas. Bottlebrush squirreltail numbers declined even more precipitously on the revegetated site, but showed no change in the undisturbed areas.

Grass cover at the ESF was found to be within the reclamation objective in terms of average cover, but not in terms of evenness of cover. The prospects of these patches filling with native grasses via natural processes are poor. Shrub density was below the objective set for the site for all species in all areas. 


\section{ACKNOWLEDGMENTS}

Reclamation of the Exploratory Shaft Facility (ESF) involved the cooperative efforts of the U.S. Department of Energy (DOE), Westinghouse Hanford Company, Morrison-Knudsen, and the Pacific Northwest Laboratory (PNL). Persons at PNL who were involved in the development and implementation of the reclamation program at the ESF included Bob Newell, Tom Page, Carol Schuler, and Jim States. Ray Bienert and Natalie Cadoret were insrumental in monitoring the progress of vegetative growth and in managing the data. Pat Boileau of DOE, Roger Grant of Kaiser Engineers Hanford, and Joe Thrasher of Westinghouse Hanford Company were responsible for ensuring the implementation of the reclamation program at the ESF. We thank them for their effectiveness in managing this program. 


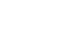




\section{CONTENT}

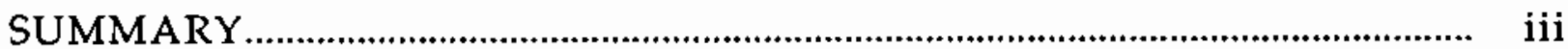

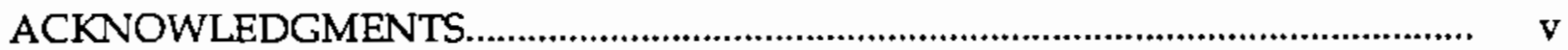

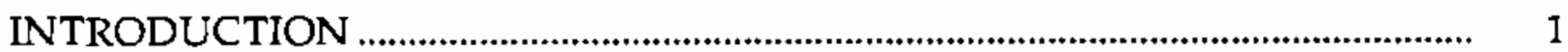

SITE DESCRIPTION ...........................................................................................

DEVELOPMENT OF THE RECLAMATION PROGRAM …....................................... 7

REVEGETATION METHODS ....................................................................... 8

METHODS FOR DETERMINING REVEGETATION SUCCESS ............................. 11

CHARACTERIZATION OF UNDISTURBED HABITAT .......................................... 15

CHARACTERIZATION OF REVEGETATED HABITAT …....................................... 21

COMPARISON OF REVEGETATED AREAS WITH UNDISTRUBED

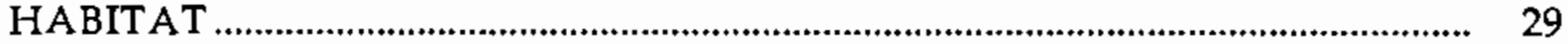

ASSESSMENT OF REVEGETATION SUCCESS....................................................

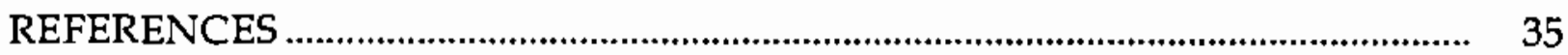




\section{FIGURES}

1 Aerial View of the Exploratory Shaft Facility Before Reclamation ............ 2

2 Location of the Exploratory Shaft Facility on the Hanford Site.................... 6

3 Percentage Cover of Principal Species on ESF Control Plots........................ 17

4 Density of Shrubs on ESF Control Plots.......................................................... 20

$5 \quad$ Successional Profiles Expected at the ESF..................................................... 32

6 Survivorship Curve for Revegetated Grasses on ESF Based on First-Year Data ......................................................................................................... 33

7 Survivorship Curve for Spiny Hopsage Planted on ESF Based on First-Year Data 


\section{TABLES}

1 Average Percentage Cover and Coefficients of Variation for Species on ESF Control Plots.......................................................................... 15

2 Repeated Measures Analysis of Variance of Percentage Cover for Species on ESF Control Plots................................................................. 16

3 Average Shrub Count per $100 \mathrm{~m}^{2}$ and Coefficients of Variation for Species on ESF Control Plots........................................................................ 18

4 Repeated Measures Analysis of Variance of Shrub Density per $100 \mathrm{~m}^{2}$ on ESF Control Plots

5 Average Plant Density per $0.25 \mathrm{~m}^{2}$ and Coefficients of Variation for Plants Growing on ESF.

6 Analysis of Variance of Grass Density per $0.25 \mathrm{~m}^{2}$ on the Revegetated ESF

7 Analysis of Variance of Grass Height on the Revegetated ESF

8 Heights of Grasses Seeded on ESF.

9 Average Number of Leaves per Plant and Coefficients of Variation for Plants Growing on ESF.

10 Analysis of Variance of Grass Leaf Number on the Revegetated ESF.

11 Average Percent Cover and Coefficients of Variation for Seeded Plants Growing on ESF.....

12 Average Percent Cover and Coefficients of Variation for Seeded PIants According to Location on ESF.

13 Average Percent Cover of Volunteer Plants Growing on ESF in April 1990.

14 Average Shrub Count per $100 \mathrm{~m}^{2}$ and Coefficients of Variation for Revegetated Shrubs on ESF. 



\section{INTRODUCTION}

The restoration of areas disturbed by activities of the Basalt Waste Isolation Project (BWIP) constitutes a unique operation at the U. S. Department of Energy's (DOE) Hanford Site, both from the standpoint of restoration objectives and the time frame for accomplishing these objectives. The BWIP reclamation program comprises three separate projects: borehole reclamation, Near Surface Test Facility (NSTF) reclamation, and Exploratory Shaft Facility (ESF) reclamation. The main focus of this report is on determining the success of the revegetation effort 1 year after work was completed. This report also provides a brief overview of the ESF reclamation program. Details of the BWIP, the history of the ESF, and the development of the reclamation program can be found in Brandt et al. (1990a).

The ESF was constructed in 1982 to the west of the 200-West Area by clearing 11.4 ha of land (Figure 1). This clearing was covered with $30 \mathrm{~cm}$ of compacted rock, gravel, and sand to provide support for a large rotary drill rig that was to bore the first large-diameter shaft to the depth of the proposed nuclear waste repository. The drill rig was mounted on a reinforced concrete foundation. A large mud pit was excavated south of the drill rig to receive drilling muds. The shaft was to be drilled to a depth of more than $1158 \mathrm{~m}$ and a diameter of more than $2.8 \mathrm{~m}$. A starter shaft was dug to a depth of $30 \mathrm{~m}$ and lined with a steel liner. Further drilling was delayed by DOE.

On December 22, 1987, President Reagan signed into law the Nuclear Waste Policy Amendments Act, which ended all repository-related characterization of the Hanford Site and required reclamation activities to be undertaken.

No specific standards and criteria were spelled out in the Nuclear Waste Policy Amendments Act that governed the reclamation of the Hanford Site; therefore, other guidelines and commitments were applied. The Nuclear Waste Policy Act requires DOE to reclaim sites disturbed during civilian radioactive waste management activities. Guidelines for decommissioning sites found unsuitable for repository development are presented in Section 7.6 of the Mission Plan for the Civilian Radioactive Waste Management Program (DOE 1985).

The Mission Plan states that a site shall be returned as nearly as practicable to the condition existing before disturbance. This became the objective of the BWIP 
N

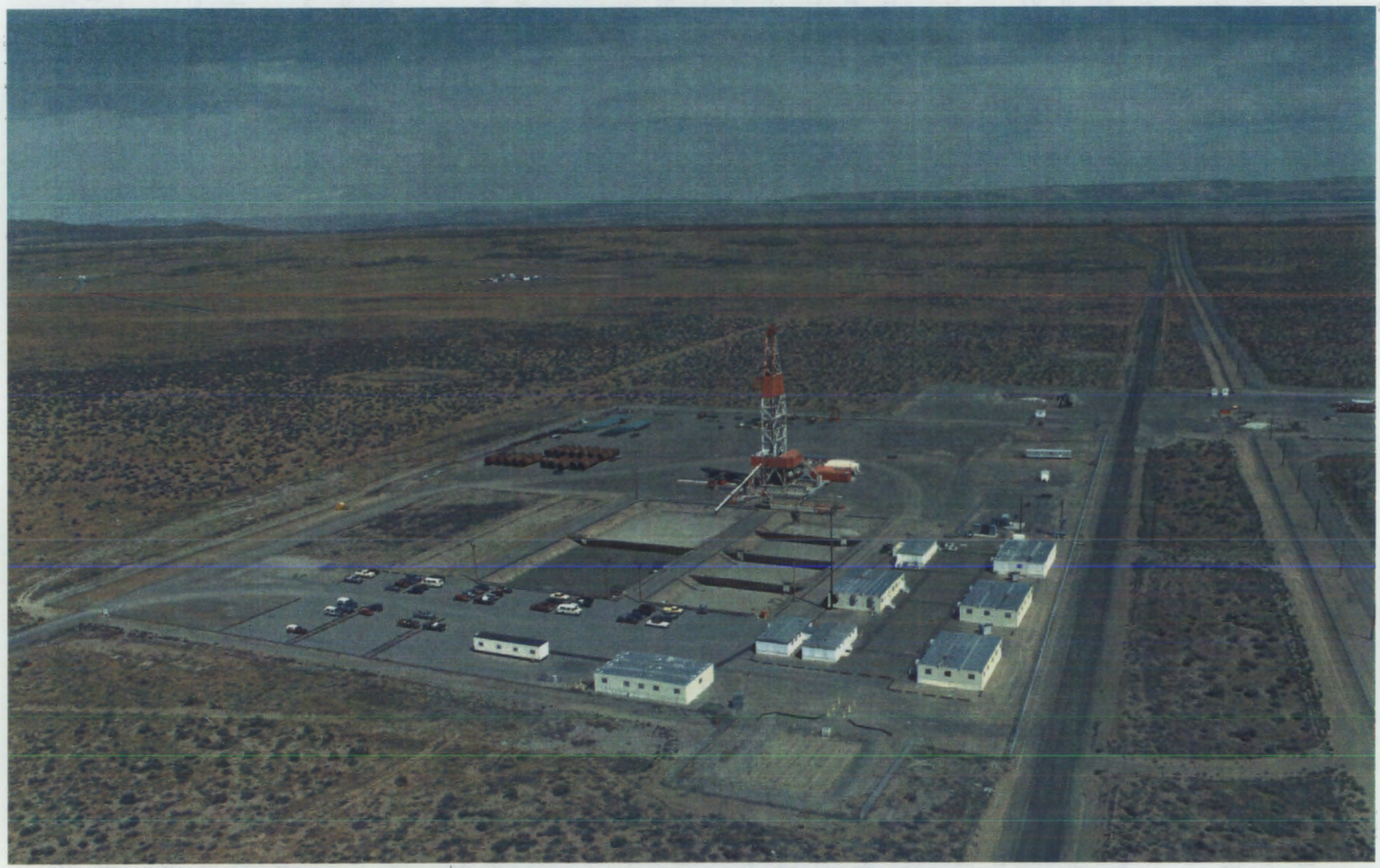

FIGURE 1. Aerial View of the Exploratory Shaft Facility Before Reclamation 
reclamation project. Although the Hanford Site was not determined to be unsuitable for licensing, for purposes of decommissioning, the provisions spelled out in the DOE Mission Plan were applied to BWIP closeout. 



\section{SITE DESCRIPTION}

The Hanford Site is located in southeastern Washington State, occupying an area of approximately $1450 \mathrm{~km}^{2}$ (Figure 2). Because of its unique history and location, the Hanford Site constitutes a significant preserve of natural resources in Washington. Because public access to the Hanford Site has been restricted since the 1940 s, it is the only expanse of nearly pristine shrub-steppe habitat in the state. Consequently, much of the Site is designated as wildlife refuge and ecological reserves.

Native plants of the shrub-steppe comprise mainly cool-season species (Rickard 1988). Vegetative growth occurs primarily during the late fall after the first rains and during spring before the extreme temperatures of summer (Rickard and Schuler 1988). The primary shrub species is big sagebrush (Artemisia tridentata). The most problematic shrub species as far as revegetation is concerned is spiny hopsage (Atriplex spinosa). No representative of this species on the Hanford Site is known to be less than 70 to 100 year old, indicating reproduction from seed is extremely poor. The principal native grasses of the lowland shrub-steppe are Sandberg bluegrass (Poa sandbergii), bottlebrush squirreltail (Sitanion hystrix), and needleand-thread grass (Stipa comata).

A number of alien annual species occur on the Hanford Site. Most of these are early successional varieties that rapidly colonize areas of soil disturbance. Such colonizers include prickly lettuce (Lactuca serriola), tansy mustard (Descurainea pinnata), tumble mustard (Sisymbrium altissimum), Russian thistle (Salsola kali), and cheatgrass (Bromus tectorum). Cheatgrass is an important nonnative component of most habitats on the Hanford Site. It is highly competitive with native species, especially on disturbed areas. Areas occupied by cheatgrass are resistant to invasion by native species (Rickard and Sauer 1982). 


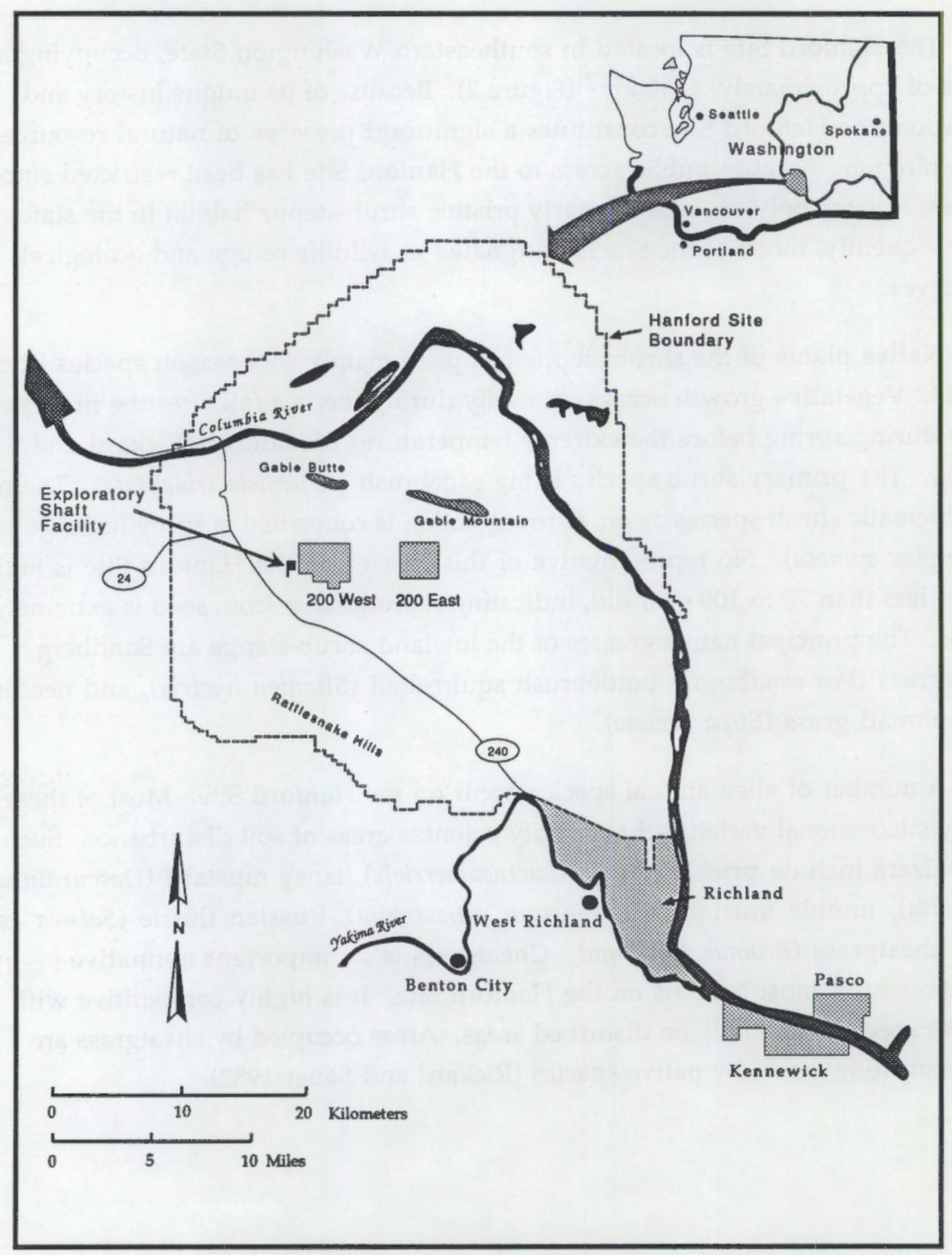

FIGURE 2. Location of the Exploratory Shaft Facility on the Hanford Site 


\section{DEVELOPMENT OF THE RECLAMATION PROGRAM}

The DOE determined on the basis of commitments made in several National Environmental Policy Act (NEPA) documents that sites disturbed by BWIP would be restored to conditions similar to natural plant communities adjacent to disturbed areas unless alternative land uses were to be implemented (DOE 1978, 1982, 1986). Primary goals were to establish self-sustaining vegetation and to produce cover conditions comparable to those existing before the disturbance. Restoration focused on re-establishment of native plant species and suppression of invading exotic species; however, disturbed sites located entirely within plant communities dominated by exotic species would not be required to be reclaimed with native species.

For the purpose of reclamation, natural vegetation is defined as the pre-existing vegetation of sites before BWIP disturbance and can generally be determined by the plant communities surrounding a disturbed site. Native vegetation is defined as plants endemic to southeastern Washington as opposed to exotic vegetation. Exotic or alien vegetation is defined as plants that are not native to southeastern Washington (i.e., have been imported in historical times from outside this region).

The DOE has determined that recovery of natural vegetation on disturbed sites and eventual restoration success will be evaluated 1 year after completion of the reclamation activities.

Constraints that define the rates and endpoints of succession at any particular site include climatic factors, edaphic (soil) characteristics, competition from native and non-native species, and seed germination and growth characteristics of the desired species. In arid areas, moisture availability and interspecific competition from alien annuals are the key constraints to reclamation.

The ESF lies in an arid zone that experiences a net input to soil moisture between November and February and a severe moisture deficit from July to October (Brandt et al. 1990a). Summer storms occasionally drop large amounts of moisture, but these are very infrequent and cannot be relied on to sustain plant growth. Precipitation during any period is unreliable: droughts have occurred in 1 of 5 years. Temperatures during the winter months are usually not so low as to preclude some plant growth at that time: indeed most of the shrubs and grasses are physiologically 
very active during this period. However, arctic air masses occasionally push the temperatures down to $-20^{\circ} \mathrm{C}$ or $-30^{\circ} \mathrm{C}$. At these temperatures, damage to unprotected growing plants may be severe. The transition period between March and June may be of primary importance to plant establishment. However, 15\% of years since 1912 have failed to receive $2.5 \mathrm{~cm}$ of precipitation during this period.

Another consideration for reclamation is that native grasses all germinate after the first significant rains in the fall, a period when soil temperatures are still high but occasional freezing air temperatures may be expected. Because native grasses are cool-season species, they perform most of their growth and nutrient storage during the winter before the ground freezes and in the spring between ground-thaw and summer heat (Chapin 1980). Grasses planted too close to ground freeze or in the spring may not have sufficient time to establish an adequate nutrient and moisture base to carry them successfully through summer dormancy.

A further consideration for reclamation deals with competition from cheatgrass. As a component of nearly all communities on the Hanford Site, cheatgrass was expected to invade the ESF site at some point. Establishment of native grasses early in the successional cycle before that invasion is essential to their continued presence at that site (Daubenmire 1970).

\section{REVEGETATION METHODS}

The strategy employed at the ESF was to introduce most of the key species from seed, supplement rainfall by irrigation, and establish spiny hopsage by planting tubeling stock. Details of the revegetation may be found in Brandt et al. (1990a). The order of work consisted of six activities: fertilization, seedbed preparation, seeding of grasses and shrubs, mulching with straw, planting hopsage tubelings, and irrigation.

A slow-release nitrogen fertilizer (sulphur-coated urea) was broadcast over the reclamation area at a rate of $34 \mathrm{~kg}$ nitrogen $/$ ha before seeding. Soil compaction was relieved by disking to a depth of $15 \mathrm{~cm}$. The seedbed was then surface-compacted using a cultipacker and roller. Seeding began November 14 and was completed November 16, 1988, under cool, rainy conditions. Seeding consisted first of broadcasting seeds of grey and green rabbitbrush (Chrysothamnus nauseosus and viscidiflorus) and big sagebrush at the rates of 0.14 and $0.28 \mathrm{~kg}$ seed $/ \mathrm{ha}$, respectively. 
Grass seed was then drilled into the seedbed using a Truax drill calibrated to deliver Sandberg bluegrass and bottlebrush squirreltail at the rates of 4.5 and $2.2 \mathrm{~kg}$ Pure Live Seed/ha, respectively. Each grass species was drilled into alternate drill furrows by loading each species into a separate seed-hopper. Soil openers were spaced at 30 $\mathrm{cm}$. Specifications for seed are listed in Brandt et al. (1990a).

Following the drilling of seed, a mulch of certified weed-free straw was blown over the seedbed at a rate of $9000 \mathrm{~kg} / \mathrm{ha}$, which was inadvertantly twice the amount recommended in the revegetation plan for the ESF. The mulch was crimped into the seedbed using a Finn Krimper. Mulching began November 16 and was completed by November 18, 1988.

Between March 8 and 15, 1989, 15-cm-long tubeling spiny hopsage was planted on the ESF. Plants were set in the ground in a clumped configuration with each plant set in a depression at least $2.5 \mathrm{~cm}$ below grade. The depressions had a radius of approximately $17 \mathrm{~cm}$. Clumps consisted of three tubelings in a triangular configuration with approximately $35 \mathrm{~cm}$ between plants. Two liters of water were applied by hand to each tubeling at the time of planting to minimize planting shock. Hopsage clumps were randomly distributed over the site at an average density of 89 clumps/ha.

As the final step in the revegetation effort, the ESF was irrigated using handmoved sprinklers from March to June 1989. Irrigation was done at the end of each month sufficient to make the cumulative precipitation on the site reach $2.5 \mathrm{~cm} / \mathrm{mo}$. 



\section{METHODS FOR DETERMINING REVEGETATION SUCCESS}

Determination of the success of reclamation of mined lands is generally based upon measures of species diversity, productivity, and wildlife usage at the reclaimed site (Hansen 1976). Specific diversity, productivity, and wildlife usage goals are generally set based on undisturbed reference areas located in regions similar to the site being reclaimed. In the BWIP reclamation effort, no direct attempt was made to re-establish original species diversity patterns due to the short time period over which reclamation was to be completed, nor were efforts directed at mimicing the productivity of undisturbed habitats. In desert ecosystems, productivity is a function of available nitrogen (Lajtha and Schlesinger 1986), water, and species composition (Rickard and Vaughan 1988). Water and nitrogen levels may be artificially elevated as a consequence of reclamation practices such as the addition of fertilizers, irrigation, and water harvesting features of the micro-landscape. These factors will temporarily elevate productivity above that expected in the mature community; thus, productivity is a poor method for estimating reclamation success unless such is measured a number of years after all reclamation efforts on the site have ceased.

Wildlife usage of shrub-steppe systems is primarily a function of vertical structure (Rosenzweig 1973; Rotenberry and Wiens 1980). Suitable understory plants, such as Sandberg bluegrass, are required as a primary food source, and a wellestablished shrub cover is also required by most species of birds and mammals as nesting sites and refuges from heat and avian predators. Some bird species, such as the western meadowlark (Sturnella neglecta) and the horned lark (Eremophila alpestris), do not require shrub cover; others, such as the long-billed curlew (Numenius americanus), require open grassland in which to nest, but also require nearby shrub communities in which to rear their young. Shrub growth may be quite slow such that little vertical diversity would be apparent on any BWIP reclamation site within 5 years of reclamation. Wildlife usage of a particular patch of habitat is constrained both by the habitat on the patch in relation to the surrounding area and by the size of the patch. Small grassland patches within a larger shrub-steppe community may show no differences in wildlife usage for any save the smallest species. Consequently, wildlife usage may be a poor measure of reclamation success of a given site, at least within the first 5 to 10 years.

Two methods are used to estimate the success of reclamation efforts for the BWIP Reclamation Project: trend analysis and spatial analysis of plant counts or 
cover per unit area. These analytical methods are applied to data on cover and density of seeded and planted species relative to the occurrence of the same species in nearby control areas.

Data were gathered over 2 years in control areas and over 1.5 years in revegetated areas to compare trends occurring on the revegetated areas with those in undisturbed habitats nearby. Examination of trends on the two types of areas allows estimation of the eventual outcome of reclamation with regard to the average density of species planted or seeded on the site. Spatial analyses are used to compare the spatial variability in plant counts and cover. A successful reclamation site should resemble the undisturbed habitat both in terms of the average density of revegetated plants as well as in terms of their spatial distribution. For example, much of a reclaimed area could be barren of seeded species, yet have a few patches of very high (and unsupportable) density seeded species. Average density values may be similar between reclaimed and undisturbed sites, yet the sites may appear very different as a result of the differences in spatial characteristics.

The vegetative community was assessed in the least disturbed habitat near the site. On May 11, 1988, four plots were located at the ESF site: one west of RRL-2B, one north of the ESF, and two west of the ESF. Sampling locations consisted of 10by $10-\mathrm{m}$ plots located at least $10 \mathrm{~m}$ from the edge of the reclamation site. Plots were marked with wooden stakes bearing the site and location designations. Canopy cover of grasses and shrubs was measured along the side of the plot nearest the disturbed area. Plant cover was measured using the point-interception method (Goodall 1953) by means of an optical point bar. The bar consists of 10 ocular scopes with crosshairs. Species were recorded whenever they intersected the view beyond the crosshairs. Sampling using the optical point bar was repeated at $1-m$ intervals starting $1 \mathrm{~m}$ from one corner of the plot. Percentage cover for any species at any sampling location was therefore simply the sum of the point interceptions for that species at that location. Shrub density was determined by counting all shrubs, by species, within the plot. Finally, all species present within the plot were tallied. Plots were sampled for cover on May 11 and June 21, 1988; April 6 and June 12, 1989; and January 11 and March 23, 1990. Sometime between May 11 and June 21, 1988, the stakes marking the plot at borehole RRL-2B were removed, and the original plot could not be relocated. Consequently, a fifth plot was added at that time south of the 
ESF. Plots were sampled for shrub density on May 11, 1988; June 12, 1989; and March 23, 1990. 



\section{CHARACTERIZATION OF UNDISTURBED HABITAT}

Annual species composed $41.8 \%$ of the total cover on undisturbed plots, while perennial species composed $15.0 \%$ (Table 1 ). Plant cover was dominated by cheatgrass, which covered over $38 \%$ of the land surface during the 2 years of monitoring. The perennial shrubs big sagebrush and grey rabbitbrush were the second and third most abundant species in terms of cover. The most common native grasses in terms of cover were Sandberg bluegrass, Indian ricegrass, and bottlebrush squirreltail, although none averaged more than $0.1 \%$ cover. The most common forb was turpentine cymopterus.

The percentage cover data were examined for statistically significant differences among plots and species and over time using a repeated-measures design Analysis of Variance with angular-transformed percentage cover as the dependent variable. Angular transformations of the data were necessary, to produce conformation to a normal distribution, which is an assumption underlying Analysis of Variance.

TABLE 1. Average Percentage Cover and Coefficients of Variation for Species on ESF Control Plots

\begin{tabular}{|c|c|c|c|c|c|}
\hline \multirow{2}{*}{ Common Name } & \multirow[b]{2}{*}{ Species } & \multirow[b]{2}{*}{ Habil } & \multicolumn{3}{|c|}{$\%$ Cover } \\
\hline & & & Average & $\mathrm{CV}(\mathrm{a})$ & $\mathrm{cV}(\mathrm{b})$ \\
\hline Cheatgrass & Bromus tectorum & Annual & 38.4 & 8.9 & 16.7 \\
\hline Big sagebrush & Artemisia tridentata & Perennial & 7.7 & 8.2 & 23.8 \\
\hline Grey rabbitbrush & Chrysothamnus nauseosus & Perennial & 6.5 & 3.6 & 32.0 \\
\hline Turpentine cymopterus & Cymopterus terebinthinus & Annual & 2.4 & 16.9 & 19.2 \\
\hline Matted cryptantha & Cryptantha circumcissa & Annual & 0.7 & 9.1 & 11.0 \\
\hline Green rabbitbrush & Chrysothamnus viscidiflorus & Perennial & 0.5 & 4.3 & 7.3 \\
\hline Jagged chickweed & Holostewm umbellatum & Annual & 0.1 & 2.0 & 1.5 \\
\hline Bottlebrush squirreltail & Sitanion hystrix & Perennial & 0.1 & 2.0 & 1.5 \\
\hline Indian ricegrass & Oryzopsis hymenoides & Perennial & 0.1 & 1.3 & 1.5 \\
\hline Sandberg bluegrass & Poa sandbergii & Perennial & 0.1 & 1.3 & 0.9 \\
\hline Bur ragweed & Ambrosia acanthicarpa & Annual & 0.05 & 1.0 & 0.7 \\
\hline Spring whitlowgrass & Draba verna & Annual & 0.05 & 1.0 & 0.7 \\
\hline Russian thistle & Salsola kali & Annual & 0.05 & 1.0 & 0.7 \\
\hline White-stemmed globe-mallow & Sphaeralcea munroana & Annual & 0.05 & 1.0 & 0.7 \\
\hline Needle-and-thread grass & Stipa comata & Perennial & 0.05 & 1.0 & 0.7 \\
\hline & AVERAGE & Perennial & 2.14 & 3.10 & 9.67 \\
\hline & AVERAGE & Annual & 5.21 & 5.13 & 6.40 \\
\hline
\end{tabular}

(a) CV=Temporal Coefficient of Variation for Cover Data Transformed as: $Y=\arcsin (\operatorname{sqr}(\mathrm{Y}+0.05))$

(b) $C V=S p a t i a l$ Coefficient of Variation for Cover Dala Transformed as: $Y^{\prime}=\arcsin (\operatorname{sqr}(Y+0.05))$ 
Because no data were available for Plot RRL-2B after May 11, 1988, this plot was excluded from the analysis. Also, plot species averages were included for the May 11, 1988, sampling of Plot ESF \#4, which was not actually first examined until June 21, 1988. Employment of plot averages allows use of the remaining data from Plot ESF \#4 without biasing the analysis.

There were no significant differences between plots in terms of their overall average plant cover [i.e., no plots were more barren or lush than others (Table 2)]. As expected, species were significantly different in their relative cover. Variance associated with sampling date (temporal pattern) and plot (spatial pattern) were approximately equal (see Mean Square in Table 2). Spatial variation accounted for $17.6 \%$ of the residual variance in percentage cover that was unexplained by species identity, and temporal variation accounted for $10.6 \%$. Spatial-temporal interaction accounted for only $1.4 \%$ of the residual variance. The interaction between sampling date and species was not large, but was highly significant. Examination of a plot of sampling date by percentage cover by species shows that this effect was a consequence of some species (primarily the annual cheatgrass) exhibiting wide differences in cover with time, while others did not (Figure 3). Examination of coefficients of variation (standard deviation/mean) show that annual species, as expected, were generally more variable over time than were perennial species (Table 1). Turpentine cymopterus, for example, had less than $1 \%$ cover in 1988 , but

TABLE 2. Repeated Measures Analysis of Variance of Percentage Cover for Species on ESF Control Plots (a)

\begin{tabular}{|c|c|c|c|c|c|}
\hline Source & df & $\begin{array}{l}\text { Sum of } \\
\text { Souares (b) }\end{array}$ & Mean Square & F-Value & P-Value \\
\hline Plot & 3 & 0.014 & 0.005 & 0.286 & 0.8354 \\
\hline Species & 14 & 5.496 & 0.393 & 23.261 & 0.0001 \\
\hline Subject(Group) & 42 & 0.709 & 0.017 & & \\
\hline Sample Date & 5 & 0.013 & 0.003 & 3.468 & 0.0049 \\
\hline Sample Date * Plot & 15 & 0.006 & 0.0004 & 0.519 & 0.9284 \\
\hline Sample Date * Species & 70 & 0.134 & 0.002 & 2.491 & 0.0001 \\
\hline Sample Date * Subject(Group) & 210 & 0.161 & 0.001 & & \\
\hline
\end{tabular}

(a) Cover Data Transformation: $Y^{\prime}=\arcsin (\operatorname{sqrt}(\mathrm{Y}+0.05)$ )

(b) Type III Sum of Square: 


$$
\begin{aligned}
& \text { A Big sagebrush } \\
& + \text { Cheatgrass } \\
& +4 \text { Grey rabbitbrush } \\
& - \text { G Green rabbitbrush } \\
& - \text { - Sandberg's bluegrass } \\
& \text { E Bottlebrush squirreltail }
\end{aligned}
$$

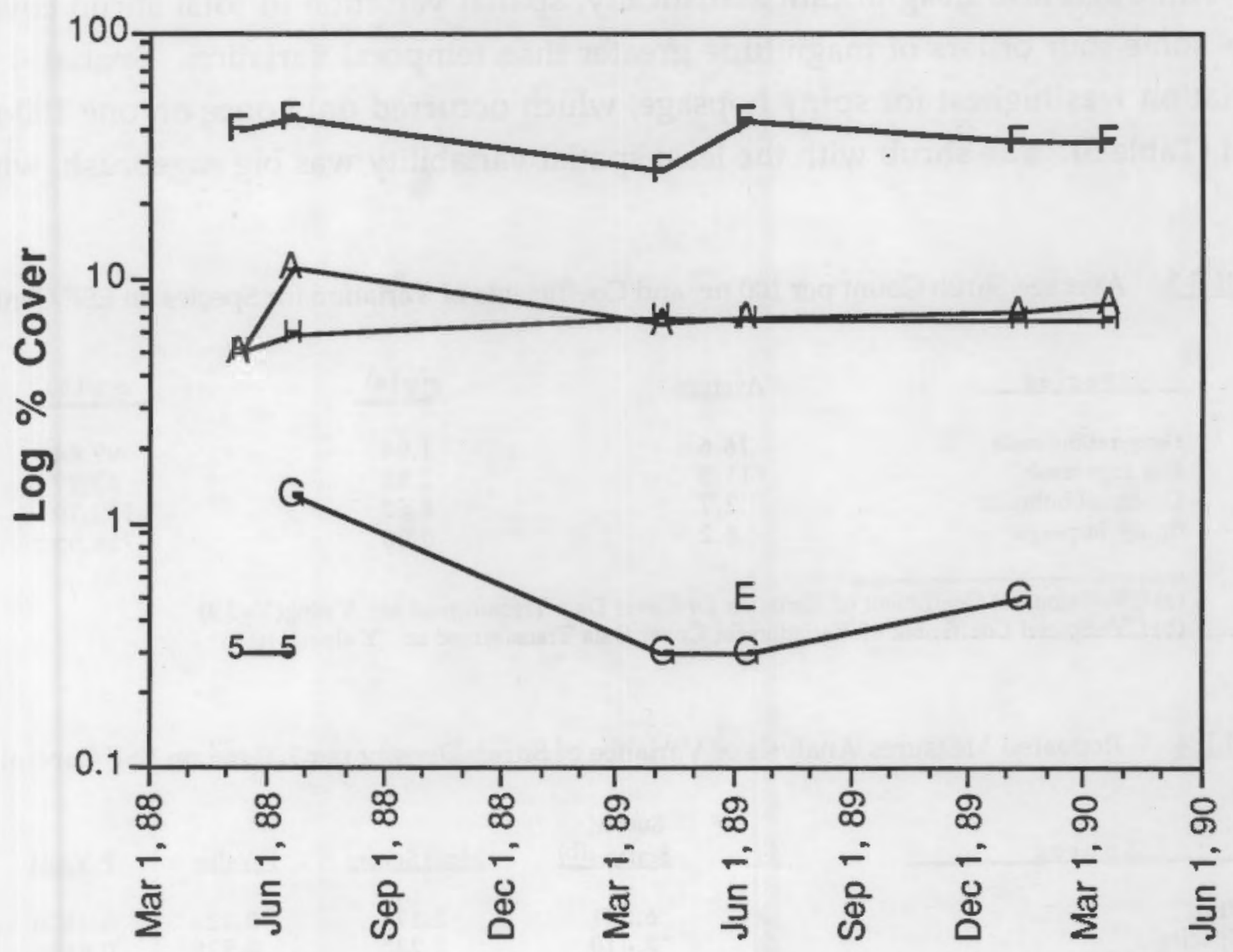

FIGURE 3. Percentage Cover of Principal Species on ESF Control Plots 
averaged over $3 \%$ over the remaining years. Despite such differences, no species exhibited a significant trend in percentage cover across years (Figure 3 ).

The most common shrub in terms of average density was grey rabbitbrush, followed by big sagebrush, green rabbitbrush, and spiny hopsage (Table 3 ). Differences among plots, species, and years were examined using repeated-measures Analysis of Variance of log-transformed density data. Because Plot RRL-2B was only measured once, it was excluded from this analysis. Temporal variation in shrub density was found to be statistically insignificant (Table 4). Thus, little in the way of reproduction or mortality occurred among any of the shrub species monitored during the 2 years of this study.

Although also insignificant statistically, spatial variation in total shrub cover was some four orders of magnitude greater than temporal variation. Spatial variation was highest for spiny hopsage, which occurred only once on one $100-\mathrm{m}^{2}$ plot (Table 3). The shrub with the least spatial variability was big sagebrush, which

TABLE 3. Average Shrub Count per $100 \mathrm{~m}^{2}$ and Coefficients of Variation for Species on ESF Control Plots

\begin{tabular}{|c|c|c|c|}
\hline Species & Average & $\mathrm{CV}(\mathrm{a})$ & $c V^{(b)}$ \\
\hline Grey rabbitbrush & 76.6 & 1.94 & 97.64 \\
\hline Big sagebrush & 11.3 & 2.81 & 63.27 \\
\hline Green rabbitbrush & 2.7 & 8.62 & 132.79 \\
\hline Spiny hopsage & 0.2 & 0.00 & 758.05 \\
\hline
\end{tabular}

(a) CV=Temporal Coefficient of Variation for Cover Data Transformed as: $Y^{\prime}=\log (Y+0.9)$

(b) CV=Spatial Coefficient of Variation for Cover Data Transformed as: $Y=\log (Y+0.9)$

TABLE 4. Repeated Measures Analysis of Variance of Shrub Density per $100 \mathrm{~m}^{2}$ on ESF Control Plots(a)

\begin{tabular}{|c|c|c|c|c|c|}
\hline Source & $\mathrm{df}$ & $\begin{array}{l}\text { Sum of } \\
\text { Squares (b) }\end{array}$ & Mean Square & F-Value & P-Value \\
\hline Plot & 3 & 6.521 & 2.174 & 0.929 & 0.4824 \\
\hline Species & 2 & 2.470 & 1.235 & 0.528 & 0.6151 \\
\hline Subject(Group) & 6 & 14.044 & 2.341 & & \\
\hline Sample Date & 2 & 0.005 & 0.003 & 0.486 & 0.6264 \\
\hline Sample Date * Plot & 6 & 0.031 & 0.005 & 0.918 & 0.5148 \\
\hline Sample Date * Species & 4 & 0.011 & 0.003 & 0.482 & 0.7489 \\
\hline Sample Date * Subject(Group) & 12 & 0.067 & 0.006 & & \\
\hline
\end{tabular}

(a) Density Data Transformation: $Y^{\prime}=\log (Y+0.9)$

(b) Type III Sum of Squares 
occurred in 4 of the 5 plots (Figure 4). Thus, the shrub assemblage in the undisturbed habitat is one in which big sagebrush is the most common shrub. Grey rabbitbrush occurs sporadically at occasionally extremely high densities. Green rabbitbrush co-occurs with grey rabbitbrush, but at less than $4 \%$ of the density. Spiny hopsage is rare.

The habitat surrounding the ESF can therefore be characterized as a big sagebrush/cheatgrass community in which native grasses occur sparsely. The aggressive alien cheatgrass is the predominant species of the understory. Other successional species such as Russian thistle are present in some areas, but they are a very minor component of the community. Grey rabbitbrush is locally abundant and tends to occur with green rabbitbrush. Spiny hopsage is scarce and never abundant even locally. 


\begin{tabular}{|l|}
\hline- Big sagebrush \\
$\square$ Spiny hopsage \\
- Grey rabbitbrush \\
$\sim$ Green rabbitbrush
\end{tabular}

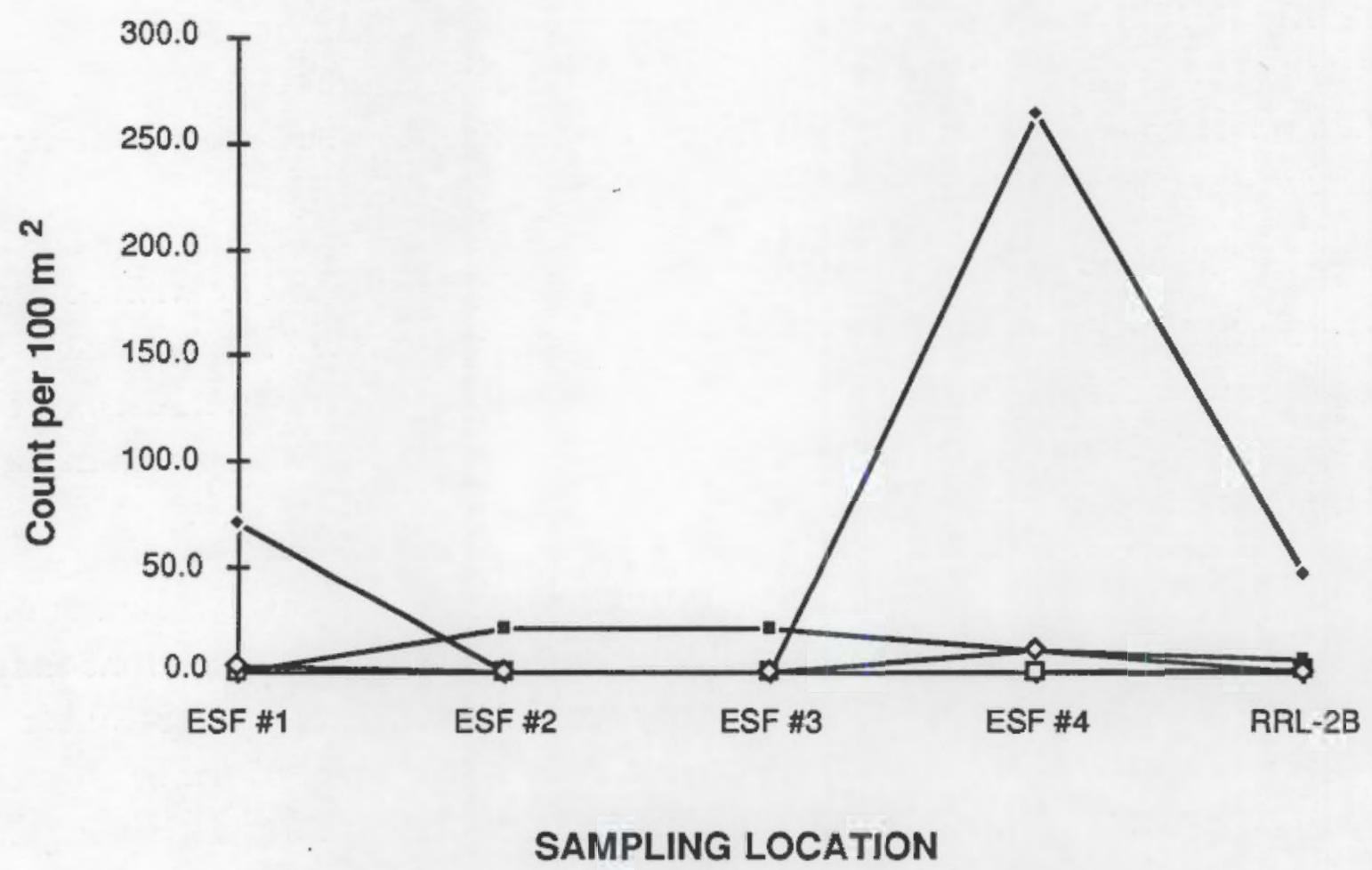

FIGURE 4. Density of Shrubs on ESF Control Plots 


\section{CHARACTERIZATION OF REVEGETATED HABITAT}

Revegetation success was assessed using a variety of methods. Grass growth and density were measured using a random sampling of 60 plot frames $\left(0.25 \mathrm{~m}^{2}\right)$ located across the ESF. All plants growing within the plot frames were counted by species by the number of leaves present. Average height of each species was also recorded. Vegetative growth was measured on March 30 and December 27, 1989. Seeded shrubs were too immature in March to allow differentiation between seeded shrubs and volunteer dicot herbs; consequently, all observations of dicots were classed as Forb in March 1989. No shrubs were encountered in the counting plots in December. On April 16, 1990, 10 permanent 10-by-10-m plots were established on the ESF: 9 on the former area of the pad and one on the mound. Shrub species occurring within these plots were counted on that date. For the purposes of statistical analyses, counts of plants were transformed to logs and counts of leaves were transformed to inverse square roots to normalize distributions and eliminate correlations between means and variances.

Density of surviving spiny hopsage tubelings was determined by walking eastwest transects across the ESF area, noting the number of planted shrubs along the transect and indicating which appeared alive and which did not. Transects were approximately $250 \mathrm{~m}$ by $5 \mathrm{~m}$; thus, an area of 0.125 ha was sampled by each transect. Eight transects were surveyed on July 13, 1989, and 6 on April 18, 1990.

Estimation of plant cover on the revegetated area could not be done using the optical point scheme for two reasons. First, plants were not distributed randomly over the ESF; instead, they occur in regularly spaced rows. The optical point bar samples in equally spaced increments, rather than at random increments; thus, data collected from such a scheme would be biased toward the extremes of the sampling space. Second, plants on the ESF were both immature and unnaturally spaced (i.e., they often occurred in extremely high densities along furrows, but had not spread outside those furrows). As these plants develop, competition will reduce density along the furrow. Also, plants will spread to cover more area outside the furrow itself. Because little of the ESF surface comprised furrows, point sampling of any kind would underestimate expected cover by mature plants. Cover was therefore estimated using a $0.25-\mathrm{m}^{2}$ plot frame divided by string into 25 squares each $0.01 \mathrm{~m}^{2}$ in size. The sizes of the squares correspond to the average areal cover of a mature 
Sandberg bluegrass plant; therefore, this plot frame samples "mature" cover equivalent to the cover estimations of mature plants that were obtained in undisturbed habitat. This frame was located randomly within three strata on the ESF, such that 23 frames were sampled on the ESF access road, 32 frames were sampled on the ESF proper, and 8 frames were sampled on the ESF mound. Species occurring within the frames were recorded by the number of squares in which they occurred. Cover sampling was conducted on April 20, 1990. For statistical analyses, cover data were transformed to arcsine square roots to meet the necessary assumptions of the tests.

Sandberg bluegrass density was higher, on average, than bottlebrush squirreltail density during both surveys (Table 5). Both Sandberg bluegrass and bottlebrush squirreltail exhibited similar and significant declines in numbers in the 9 months between the first and last assessment (Table 6). Spatial variation increased for both species between the first and last surveys, indicating distributions had become more patchy as a consequence of mortality (Table 5). The survey interval covered the most stressful portion of the year for plants on the Hanford Site (i.e., summer heat and drought). Cold season grasses become dormant during this period, relying for survival on metabolic stores generated during the preceding cool months. A severe low-temperature event occurred during February 1989, which burnt the aboveground portion of most plants established on the ESF. Plants thus had to employ stored energy and structural components to regenerate lost tissue, which probably left many in poor condition to enter dormancy.

TABLE 5. Average Plant Density per $0.25 \mathrm{~m}^{2}$ and Coefficients of Variation for Plants Growing on ESF

\begin{tabular}{|c|c|}
\hline Sampling Date & Species \\
\hline March 30, 1989 & Sandberg bluegrass \\
\hline December 27, 1989 & Sandberg bluegrass \\
\hline March 30, 1989 & Bottlebrush squirreltai \\
\hline December 27, 1989 & Bottlebrush squirreltai \\
\hline March 30, 1989 & Forb \\
\hline
\end{tabular}


TABLE 6. Analysis of Variance of Grass Density per $0.25 \mathrm{~m}^{2}$ on the Revegetated ESF ${ }^{(\mathrm{a})}$

\begin{tabular}{lrcccrc}
\multicolumn{1}{c}{ Source } & df & & $\begin{array}{c}\text { Sum of } \\
\text { Squares }(b)\end{array}$ & Mean Square & E-Value & P-Value \\
\cline { 2 - 5 } Date & 1 & 18.286 & 18.286 & 96.925 & 0.0001 \\
Species & 2 & 12.773 & 6.387 & 33.852 & 0.0001 \\
Date * Species & 1 & 0.0003 & 0.0003 & 0.002 & 0.9669 \\
Residual & 191 & 36.034 & 0.189 & & \\
TOTAL & 195 & 92.556 & & &
\end{tabular}

(a) Density Data Transformation: $Y^{\prime}=\log (Y+0.9)$

(b) Type III Sum of Squares

This interpretation is borne out by analysis of plant height changes during the same interval (Table 7). In the March survey, Sandberg bluegrass was taller, on average, than when measured in December (Table 8). During the same interval, bottlebrush squirreltail gained one third in height, indicating that Sandberg bluegrass probably suffered more damage as a consequence of the freezing temperatures. Not all Sandberg bluegrass plants suffered equally; many remained unaffected (hence the larger Coefficient of Variation for the December measurement).

TABLE 7. Analysis of Variance of Grass Height on the Revegetated ESF

\begin{tabular}{lrrrrrr}
\multicolumn{1}{c}{ Source } & df & $\begin{array}{c}\text { Sum of } \\
\text { Squares }(a)\end{array}$ & Mean Square & E-Value & P-Value \\
\cline { 2 - 5 } Date & 1 & 3.133 & 3.133 & 5.526 & 0.0204 \\
Species & 2 & 27.875 & 13.938 & 24.581 & 0.0001 \\
Date * Species & 1 & 3.656 & 3.656 & 6.448 & 0.0124 \\
Residual & 119 & 67.474 & 0.567 & & \\
TOTAL & 123 & 102.138 & & &
\end{tabular}

(a) Type III Sum of Squares

TABLE 8. Heights of Grasses Seeded on ESF

Sampling Date

March 30, 1989

December 27, 1989

March 30, 1989

December 27, 1989

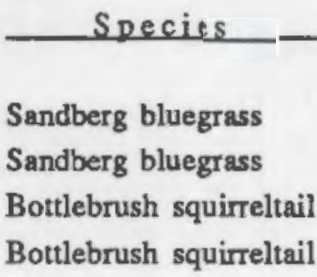

Sandberg bluegrass

Bottlebrush squirreltail

Bottlebrush squirreltail
Average

2.09

2.05

3.00

4.00

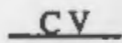

31.47

44.08

25.46

21.65 
Surviving plants set new leaves and expanded their basal areas during the interval between measurements. Both species averaged more leaves in December than they had the previous March (Table 9). Bottlebrush squirreltail performed considerably better than Sandberg bluegrass (Table 10). Surviving bottlebrush squirreltail plants nearly doubled the number of leaves per plant, while Sandberg bluegrass only experienced a $25 \%$ increase.

Most of the species seeded on the ESF managed to establish themselves during the first full year after seeding. The most successful revegetated plant in terms of average percentage cover as measured in April 1990 was Sandberg bluegrass, followed by bottlebrush squirreltail (Table 11). Shrubs had the lowest cover. Green rabbitbrush seedlings have not been discovered on any of the assessment plots. Spatial variation was extremely high for all species.

TABLE 9. Average Number of Leaves per Plant and Coefficients of Variation for Plants Growing on ESF

\begin{tabular}{llcr} 
Sampling Date & \multicolumn{1}{c}{ Species } & Average & CV(a) \\
& & & \\
March 30, 1989 & Sandberg bluegrass & 1.6 & 6.77 \\
December 27, 1989 & Sandberg bluegrass & 2.0 & 18.07 \\
March 30,1989 & Bottlebrush squirreltail & 2.0 & 4.38 \\
December 27, 1989 & Bottlebrush squirreltail & 3.6 & 25.24
\end{tabular}

(a) Leaf Number Data Transformation: $Y=1 / \sqrt{ } Y$

TABLE 10. Analysis of Variance of Grass Leaf Number on the Revegetated ESF(a)

\begin{tabular}{lrccrrr}
\multicolumn{1}{c}{ Source } & df & $\begin{array}{c}\text { Sum of } \\
\text { Squares(b) }\end{array}$ & Mean Square & F-Value & P-Value \\
Date & 1 & 0.056 & & 0.056 & 7.468 & 0.0072 \\
Species & 2 & 0.210 & 0.105 & 14.135 & 0.0001 \\
Date * Species & 1 & 0.027 & 0.027 & 3.655 & 0.0583 \\
Residual & 119 & 0.889 & 0.007 & & \\
TOTAL & 123 & 1.182 & & & &
\end{tabular}

(a) Leaf Number Data Transformation: $Y^{\prime}=1 / \mathrm{Y}$

(b) Type III Sum of Squares 
TABLE 11. Average Percent Cover and Coefficients of Variation for Seeded Plants Growing on ESF

\begin{tabular}{lccc}
\multicolumn{1}{c}{ Species } & & Average & CV(a) \\
\cline { 1 - 1 } Sandberg bluegrass & & & \\
Bottlebrush squirreltail & & 3.79 & 83.96 \\
Grey rabbitbrush & & 0.89 & 111.45 \\
Big sagebrush & & 0.44 & 181.63 \\
Green rabbitbrush & & 0.0 & 182.86 \\
& & & 0.0
\end{tabular}

(a) Percent Cover Data Transformation: $Y=\arcsin (\operatorname{sqr}(\mathrm{Y}+0.05))$

Spatial variability was examined in more detail by examining percentage cover according to the general location in which the sample was taken (i.e., the access road, the main pad, or the mound area). Percentage cover for each of the seeded species within these areas was examined using contrast analysis in which cover on the mound area was compared to cover elsewhere. The mound area supported many fewer species than did the remainder of the ESF (Table 12). Although no big sagebrush or grey rabbitbrush was found on the mound, cover by these species was generally so low that the contrast was not statistically significant. The access road was the only area in which big sagebrush seedlings occurred in the cover assessment.

Seeded species were not the most abundant plants on the revegetated areas. Cheatgrass and Russian thistle were the two most abundant species (Table 13). Cover by cheatgrass was highest on the access road and least (absent) on the mound. Russian thistle cover was highest on the pad and least on the mound. The only species present on the mound were Russian thistle and Sandberg bluegrass.

Shrub counts were highest overall for grey rabbitbrush as determined from counts on the 10 permanent plots (Table 14). The second most prevalent shrub in terms of density was spiny hopsage, which was planted rather than seeded. Approximately one third fewer spiny hopsage were alive in April 1990 than had been found alive in July of the previous year. Much of this mortality was apparently due to grazing by blacktailed jackrabbits (Lepus californicus). Big sagebrush did poorly, as noted earlier, and had an extremely patchy occurrence. Green rabbitbrush was not observed. No shrubs occurred on the mound area. 
TABLE 12. Average Percent Cover and Coefficients of Variation for Seeded Plants According to Location on ESF

\begin{tabular}{|c|c|c|c|}
\hline Location & Species & Average & $\mathrm{CV}(\mathrm{a})$ \\
\hline \multirow[t]{5}{*}{ Access Road } & Sandberg bluegrass & 13.22 & 63.80 \\
\hline & Bottlebrush squirreltail & 3.48 & 115.75 \\
\hline & Grey rabbitbrush & 0.87 & 122.58 \\
\hline & Big sagebrush & 1.22 & 180.70 \\
\hline & Green rabbitbrush & 0.0 & 0.0 \\
\hline \multirow[t]{5}{*}{ Main Pad } & Sandberg bluegrass & 18.25 & 82.73 \\
\hline & Bottlebrush squirreltail & 4.62 & 94.44 \\
\hline & Grey rabbitbrush & 1.12 & 230.43 \\
\hline & Big sagebrush & 0.0 & 0.0 \\
\hline & Green rabbitbrush & 0.0 & 0.0 \\
\hline \multirow[t]{5}{*}{ Mound } & Sandberg bluegrass (b) & 5.50 & 182.81 \\
\hline & Bottlebrush squirreltail(c) & 0.0 & 0.0 \\
\hline & Grey rabbitbrush (d) & 0.0 & 0.0 \\
\hline & Big sagebrush (e) & 0.0 & 0.0 \\
\hline & Green rabbitbrush & 0.0 & 0.0 \\
\hline
\end{tabular}
(a) Percent Cover Data Transformation: $Y=\arcsin (\operatorname{sqr} t(\mathbf{Y}+0.05)$ )
(b) Contrast analysis, Mound vs. other: $F_{1,60}=4.733, P=0.0335$
(c) $\mathrm{F}_{1,60}=5.205, \mathrm{P}=0.0261$
(d) $F_{1}, 60=0.866, P=0.3558$
(e) $\mathrm{F}_{1,60}=0.547, \mathrm{P}=0.4624$ 
TABLE 13. Average Percent Cover of Volunteer Plants Growing on ESF in April 1990

Location

Access Road

Main Pad

Mound

$\begin{array}{ll}\text { Access Road } & \text { Bur ragweed } \\ \text { Astragalus sp } \\ \text { Cheatgrass } \\ \text { Tansy mustard (Descurania pinviata) } \\ \text { Broom buckwheat (Eriogonum viminium) } \\ \text { Prickly lettuce (Lactuca serriola) } \\ \text { Hoary aster (Machaeranthera canescens) } \\ \text { Russian thistle } \\ \text { Bur ragweed } \\ \text { Astragalus sp } \\ \text { Cheatgrass } \\ \text { Tansy mustard } \\ \text { Broom buckwheat } \\ \text { Prickly lettuce } \\ \text { Hoary aster } \\ \text { Russian thistle } \\ \text { Bur ragweed } \\ \text { Astragalus sp } \\ \text { Cheatgrass } \\ \text { Tansy mustard } \\ \text { Broom buckwheat } \\ \text { Prickly lettuce } \\ \text { Houry aster } \\ \text { Russian thistle }\end{array}$

Average
0.0

0.17

69.22

0.17

0.17

0.17

0.35

17.04

0.12

0.0

2.75

0.50

0.0

0.38

0.0

28.25

0.0

0.0

0.0

0.0

0.0

0.0

0.0

6.00

TABLE 14. Average Shrub Count per $100 \mathrm{~m}^{2}$ and Coefficients of Variation for Revegetated Shrubs on ESF

\begin{tabular}{lcrr}
\multicolumn{1}{c}{ Species } & Average & $\mathrm{CV}(\mathrm{a})$ \\
\cline { 4 - 4 } Grey rabbitbrush & & \\
Big sagebrush & & 3.00 & 69.51 \\
Green rabbitbrush & 0.10 & 771.20 \\
Spiny hopsage 1988 (Planted) & 0.00 & 0.00 \\
Spiny hopsage 1989 & 2.67 & \\
Spiny hopsage 1990 & 1.16 & 37.76 \\
& & 0.77 & 33.50
\end{tabular}

(a) Density Data Transformation: $Y^{\prime}=\log (Y+0.9)$ 



\section{COMPARISON OF REVEGETATED AREAS WITH UNDISTURBED HABITAT}

In terms of average cover, both seeded grass species on the ESF compared favorably at the end of their first full year of growth with their counterparts in the neighboring undisturbed habitat. Cover by Sandberg bluegrass averaged over 100 times that in the surrounding habitat; average cover of bottlebrush squirreltail was even higher. Bottlebrush squirreltail is a common species throughout the shrubsteppe on the Hanford Site in that it occurs in most 10-by-10-m samples in most habitats (Brandt et al. 1990b). However, generally only one to several plants occur within these samples, composing generally less than $0.5 \%$ of total cover. Cover by both species was similar on the access road and main pad of the ESF. Cover by Sandberg bluegrass on the mound also averaged higher than in the surrounding habitat. No bottlebrush squirreltail occurred on the mound.

Growth by native grasses on the ESF was significantly more patchy than in the surrounding undisturbed habitat. Spatial coefficients of variation for Sandberg bluegrass were two orders of magnitude greater on the access road and the former ESF pad area than in undisturbed areas. Spatial variability on the mound was 200 times that of undisturbed habitat and over twice that of other areas on the ESF.

Plant numbers of both seeded grasses exhibited marked declines during the first year after seeding. Sandberg bluegrass numbers dropped by an order of magnitude on the revegetated area, but showed no significant change during the same period on undisturbed areas. Bottlebrush squirreltail numbers declined even more precipitously on the revegetated site, but showed no change in the undisturbed areas. Even so, the average density of this plant on most of the revegetated site in December 1989 was several orders of magnitude greater than that in the surrounding area. The mound area supported insufficient numbers of both species relative to undisturbed areas.

Shrub numbers and percentage cover were both significantly lower on the ESF than in the surrounding habitat for all species except spiny hopsage. Seeded shrubs performed much poorer than did spiny hopsage, which was planted from tubeling stock. Grey rabbitbrush was the most common species in terms of average density on both the ESF and in undisturbed habitat, although its density on the ESF averaged over 20 times less than in undisturbed habitat. This species occurred in 
greatest abundance on the ESF pad area and not at all on the mound. Patchiness on the revegetated sites matched that of the undisturbed habitat, as evidenced by the similar coefficients of spatial variation for the two habitats (see Tables 3 and 14).

Big sagebrush numbers averaged some 100 times less on the ESF than in undisturbed habitat, although plants were far from evenly distributed. No big sagebrush was found in any of the cover assessment plots on the ESF pad or mound, and only one plant was found in the nine permanent plots on the ESF pad. No plants were found on the mound. Consequently, spatial variability for this species was much higher on the revegetated site than in the surrounding habitat.

No green rabbitbrush has been detected on the ESF. This is in contrast to an average density of 2.7 plants $/ 100 \mathrm{~m}^{2}$ in the undisturbed community.

Spiny hopsage density on the ESF was over three times that in the surrounding habitat in April 1990. Spatial distribution was much more even on the ESF as well. However, no plants were detected on the mound. 


\section{ASSESSMENT OF REVEGETATION SUCCESS}

On average, seeded grasses performed well on the ESF. Despite severe mortality induced by extreme weather during their first winter of growth, grasses continued to expand their basal areas through the production of new leaves and to gain height. However, coefficients of spatial variability were extremely high. These extreme values quantify the visual impression that a few areas of the ESF support exceptional stands of seeded grasses, while others support no grasses at all. The mound area is a case in point: this area was nearly barren of all vegetation, seeded or volunteer, at the last assessment in April 1990. Cover by alien annuals, particularly Russian thistle, was quite high on the revegetated sites, but within the range expected (Figure 5). Cheatgrass cover was low, as expected, but will likely increase dramatically within the next year.

Some mortality was expected to occur as a consequence of competition among neighboring plants. However, the magnitude of the decrease was not expected (see Figure 5) and is presumed to be primarily a consequence of the extreme conditions these plants experienced during their first winter. Another factor contributing to this decline is soil moisture differences around the site. The mound area soils comprise gravel spoil material with a large sand fraction (Brandt et al. 1990a). This material has very low water holding capacity (Bradshaw and Chadwick 1980). Similar material may be found in the former mud pit area. Soil moisture is commonly the principal factor limiting productivity in the northwestern shrubsteppe plant communities (Sneva 1978). Competition for moisture occurs most heavily between species that draw water from similar depths in the soil column. Competition will thus be intraspecific among seeded grasses and interspecific between seeded grasses and alien annuals, primarily cheatgrass. Russian thistle is a warm-season plant with a long tap-root. Consequently, its main period of growth and moisture use occurs well after the cool-season species have ceased production.

Competition for moisture is expected to continue, resulting in greater thinning of the seeded grasses. Assuming that an exponential decay function (i.e., $\mathrm{N}_{t}=\mathrm{N}_{\mathrm{O}} \mathrm{e}^{\mathrm{rt}}$ where $\mathrm{N}_{\mathrm{t}}=$ number at time $\mathrm{t}, \mathrm{N}_{\mathrm{O}}=$ number at time $0, \mathrm{r}=$ population growth rate, and 


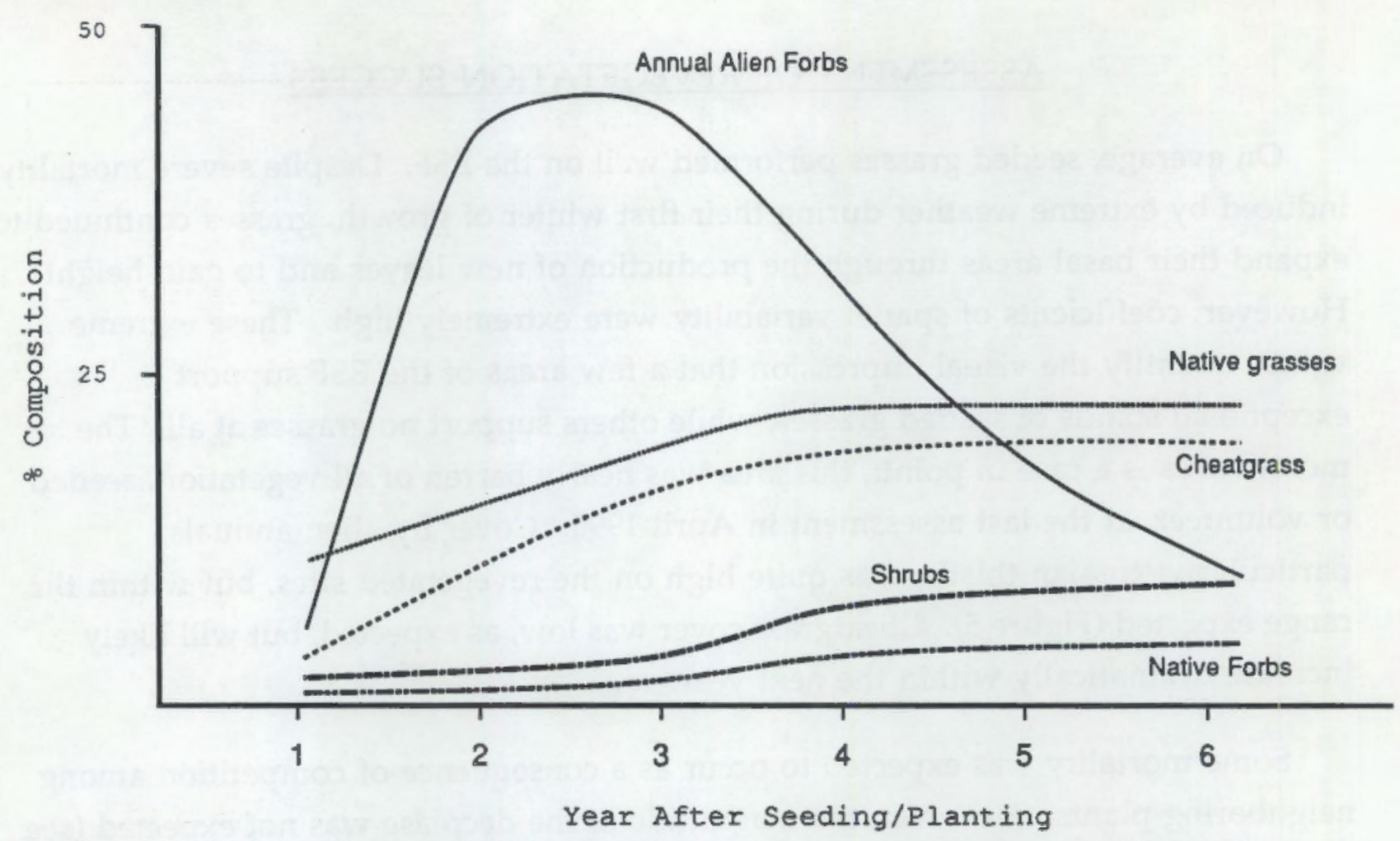

FIGURE 5. Successional Profiles Expected at the ESF (modified from DePuit and Redente 1988)

$t=$ time) describes the change in plant numbers per unit time [this function is standard for growth or survivorship functions over time for biological populations (e.g., Clow and Urquhart 1984)], Sandberg bluegrass on the ESF would be expected to reach a density similar to that in undisturbed habitat (approximately 300 plants per $0.25 \mathrm{~m}^{2}$ ) within the next year (Figure 6), based on the loss rate measured between spring and winter $1989(\mathrm{r}=-0.2$ plants $/ \mathrm{mo})$. Bottlebrush squirreltail would reach a density equivalent to that in the surrounding habitat $\left(\sim 2\right.$ plants $\left./ 100 \mathrm{~m}^{2}\right)$ within a year, based on the observed rate of decline in numbers $(r=-0.25$ plants $/ \mathrm{mo})$. This rate of decline will be mitigated by reproduction by established plants on the ESF, as well as by increased hardiness in surviving plants. At the present time, there are no direct means of predicting the equilibrium population density or future cover.

Density of seeded shrubs was well below that in the surrounding habitat. Green rabbitbrush is totally absent from the revegetated areas. However, shrubs are more 


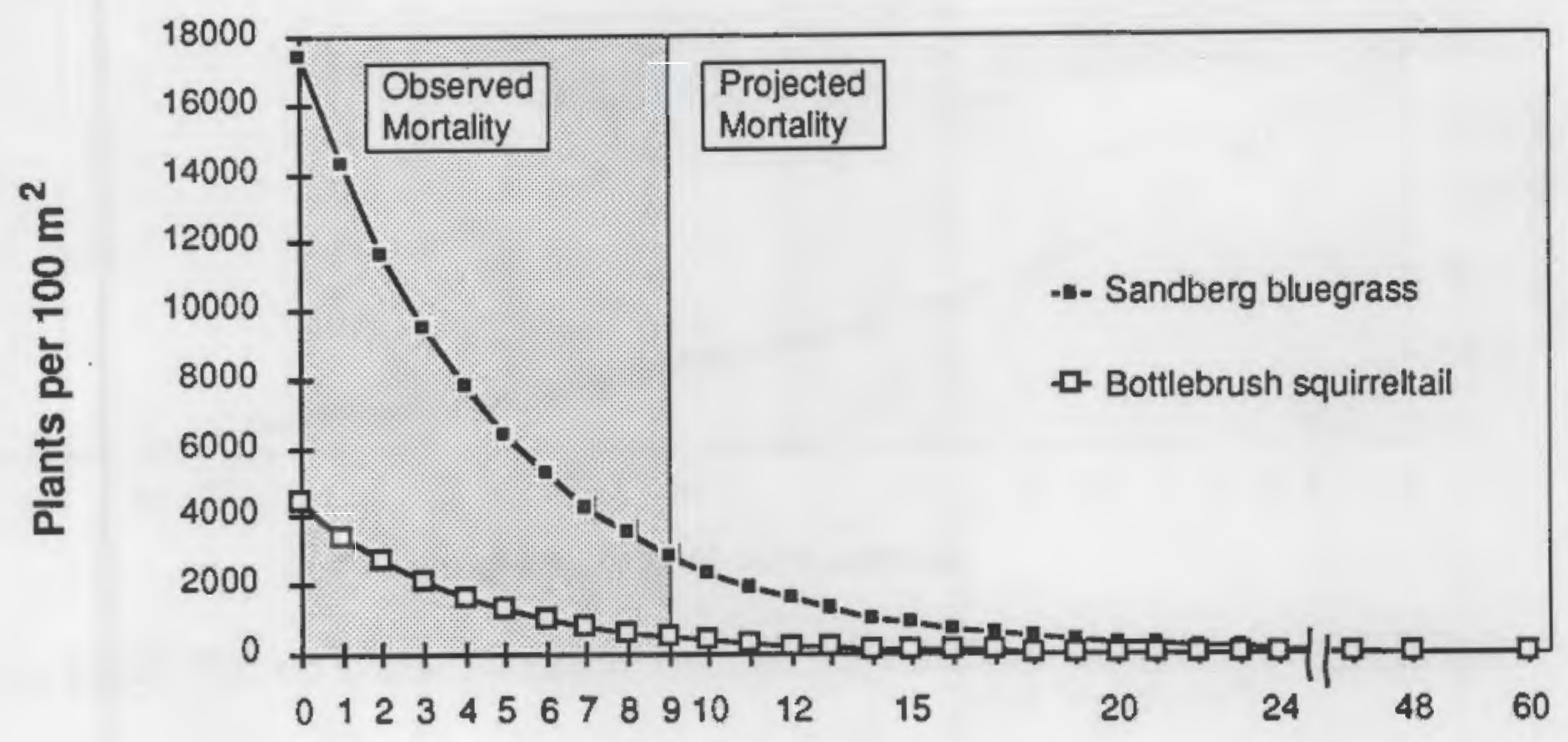

\section{Months After First Measurement}

FIGURE 6. Survivorship Curve for Revegetated Grasses on ESF Based on First-Year Data

likely to be able to increase their numbers within the next few years as a consequence of establishment from seed produced by mature plants nearby. Rates of shrub regeneration within the shrub-steppe have not been studied. Without at least another growth season of monitoring, it is not possible to provide estimates of eventual shrub density on the site.

Although spiny hopsage numbers were consistent with the surrounding area in April 1990, it is doubtful that they will remain so. Mortality rates averaged over $50 \%$ during the first several months after planting (Brandt 1990a) and continued to be nearly $34 \%$ over the next 9 months. Again assuming an exponential decay function describes the mortality of these shrubs, their density would decline to below the numbers in the surrounding habitat ( 20 plants/ha) within the next 2 years (Figure 7 ), using the average rate of decline in numbers over the period since the shrubs were planted $(r=-0.11$ plants $/ \mathrm{mo})$. 


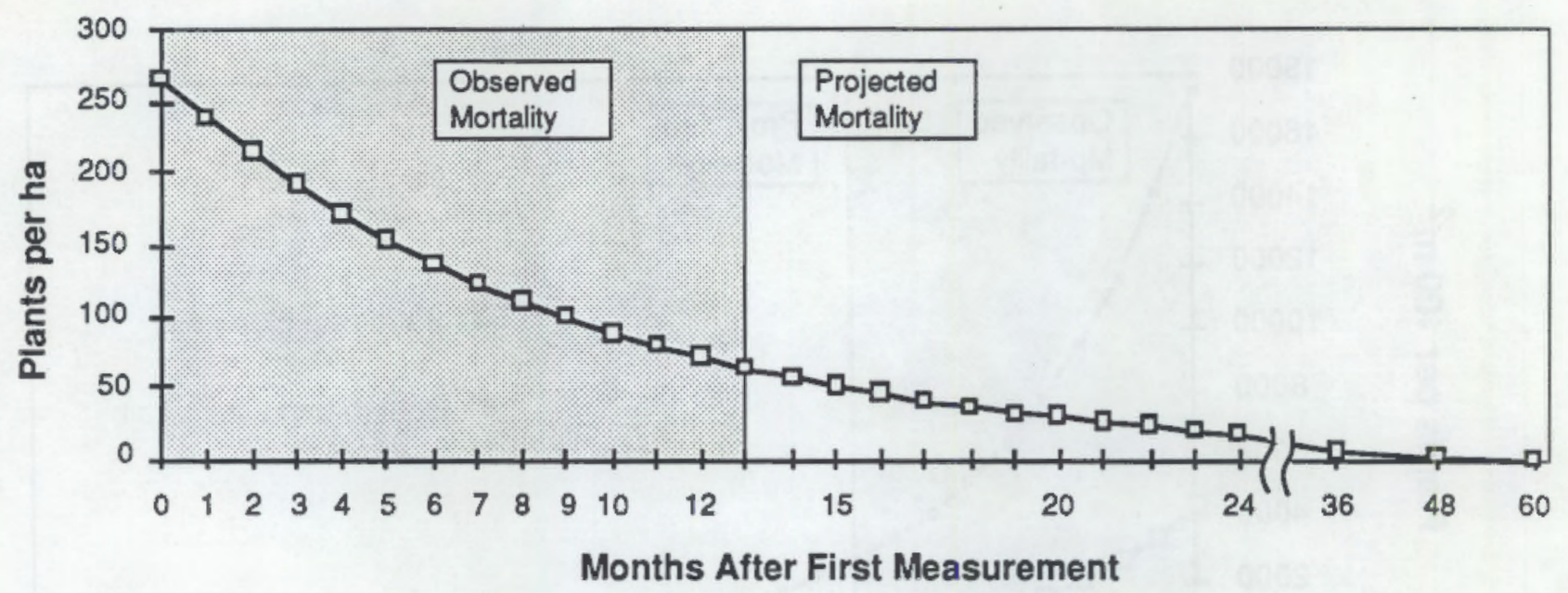

FIGURE 7. Survivorship Curve for Spiny Hopsage Planted on ESF Based on First-Year Data

In summary, the grass cover at the ESF is within the reclamation objective in terms of average cover, but not in terms of evenness of cover. Many large areas (greater than 0.5 ha each) are without any native grasses. The mound area is significant in that respect, being nearly devoid of all plant cover of any kind. Based on previous experience of secondary succession at the Hanford Site (Rickard and Sauer 1982), it is unlikely that native grasses will re-establish on these patches without intervention. The magnitude of the decline in density during the first year and a half after seeding was unexpected. Without longer-term assessment, it will not be possible to determine whether this trend will continue. Shrub density is currently below the objective set for the site for all species in all areas. There are no data to allow estimation of the likelihood of natural recolonization by shrubs. 


\section{REFERENCES}

Bradshaw, A. D., and M. J. Chadwick. 1980. The Restoration of Land. University of California Press, Berkeley, California.

Brandt, C. A., W. H. Rickard, Jr., and M. G. Hefty. 1990a. Interim Reclamation Report: Basalt Waste Isolation Project Exploratory Shaft Site. PNL-7270, Pacific Northwest Laboratory, Richland, Washington.

Brandt, C. A., W. H. Rickard, Jr., and M. G. Hefty. 1990b. Interim Reclamation Report Basalt Waste Isolation Project Boreholes 1989. PNL-7280, Pacific Northwest Laboratory, Richland, Washington.

Chapin, F. S., III. 1980. "The Mineral Nutrition of Wild Plants." Ann. Reo. Ecol. Syst. 11:233-260.

Clow, D. J., and N. S. Urquhart. 1984. Mathematics in Biology. Ardsley House, New York.

Daubenmire, R. 1970. Steppe Vegetation of Washington. Technical Bulletin 62, Washington Agricultural Experiment Station, Pullman, Washington.

DePuit, E. J., and E. F. Redente. 1988. "Manipulation of Ecosystem Dynamics on Reconstructed Semiarid Lands." In The Reconstruction of Disturbed Arid Lands, ed. E. B. Allen, pp. 162-204. Westview Press, Boulder, Colorado.

Goodall, D. W. 1953. "Point-Quadrat Methods for the Analysis of Vegetation." Australian J. Botany 1:457-461.

Hansen, R. P. 1976. "Statutory and Regulatory Aspects of Mined Land Reclamation." In Reclamation of Western Surface Mined Lands, ed. K. C. Vories, pp. 1-7. Ecology Consultants, Inc., Boulder, Colorado.

Lajtha, K., and W. H. Schlesinger. 1986. "Plant Response to Variations in Nitrogen Availability in a Desert Shrubland Community." Biogeochemistry 2:29-37.

Rickard, W. H., Jr. 1988. Natural Vegetation at the Proposed Reference Repository Location in Southeastern Washington. PNL-6402, Pacific Northwest Laboratory, Richland, Washington.

Rickard, W. H., Jr., and R. H. Sauer. 1982. "Self-Revegetation of Disturbed Ground in the Deserts of Nevada and Washington." Northw. Sci. 56:41-47.

Rickard, W. H., Jr., and C. A. Schuler. 1988. Descriptions of Plant Communities at the Proposed Reference Repository Location and Implications for Reclamation of Disturbed Ground. PNL 6494, Pacific Northwest Laboratory, Richland, Washington 
Rickard, W. H., Jr., and B. E. Vaughan. 1988. "Plant communities: Characteristics and Responses." In Shrub-Steppe: Balance and Change in a Semi-Arid Terrestrial Ecosystem, eds. W. H. Rickard, Jr., L. E. Rogers, B. E. Vaughan, and S. F. Liebetrau, pp. 109-181. Elsevier, Amsterdam.

Rosenzweig, M. L. 1973. "Habitat Selection Experiments with a Pair of Coexisting Heteromyid Rodent Species." Ecology 54: 111-117.

Rotenberry, J. T., and J. A. Wiens. 1980. "Habitat Structure, Patchiness, and Avian Communities in North American Steppe Vegetation: A Multivariate Analysis." Ecology 61:1228-1250.

Sneva, F. A. 1978. "Nitrogen and Sulphur Impacts on the Cold Desert Biome." In Proceedings, 1st International Rangeland Conference, ed. D. N. Hyder, pp. 678-680. Society for Range Management, Denver, Colorado.

U. S. Department of Energy (DOE). 1978. Environmental Assessment, National Waste Terminal Storage Program, Near Surface Test Facility, Hanford Reservation, Washington. DOE/EA-0052, U. S. Department of Energy, Washington, D.C.

U. S. Department of Energy (DOE). 1982. Environmental Assessment, National Waste Terminal Storage Program, Exploratory Shaft Construction, Hanford Reservation, Washington. DOE/EA-0188, U. S. Department of Energy, Washington, D.C.

U. S. Department of Energy (DOE). 1985. Mission Plan for the Civilian Radioactive Waste Management Program. DOE/RW-0005, Vol. 1, U. S. Department of Energy, Office of Civilian Radioactive Waste Management, Washington, D.C.

U. S. Department of Energy (DOE). 1986. Environmental Assessment, Reference Repository Location, Hanford Site, Washington. DOE/RW-0070, U. S. Department of Energy, Office of Civilian Radioactive Waste Management, Washington, D.C. 



\section{DISTRIBUTION}

No. of

Copies

OFFSITE

2 DOE/Office of Scientific and Technical Information

\section{ONSITE}

3 DOE Richland Operations Office

J. H. Anttonen

J. D. Furubotten

A. G. Lassila

5 Westinghouse Hanford Company

C. R. Haggerty

D. E. Mahagin

J. E. Thrasher

P. H. Turner

BWIP Records Center

4 Kaiser Engineers Hanford

K. C. Burgard

R. E. Grant

N. M. Hutchins

R. L. Newell
No. of

Copies

45 Pacific Northwest Laboratory

R. W. Bienert

C. A. Brandt (10)

N. A. Cadoret

D. D. Dauble

J. W. Falco

R. H. Gray (5)

J. M. Hales

P. C. Hays

M. G. Hefty

T. L. Page

W. T. Pennell

W. H. Rickard, Jr. (10)

L. E. Rogers

R. L. Skaggs

J. B. States

H. E. Westerdahl

R. K. Woodruff

Publishing Coordination

Technical Report Files (5) 